Chronic Obstructive Pulmonary Diseases: Journal of the COPD Foundation

\author{
Original Research
}

\title{
Plasma Cathelicidin is Independently Associated with Reduced Lung Function in COPD: Analysis of the Subpopulations and Intermediate Outcome Measures in COPD Study Cohort
}

Robert M. Burkes, $\mathrm{MD}^{1}$ Agathe S. Ceppe, $\mathrm{MS}^{2}$ David J. Couper, $\mathrm{PhD}^{3}$ Alejandro P. Comellas, $\mathrm{MD}^{4}$ J. Michael Wells, $\mathrm{MD}^{5}$ Stephen P. Peters, MD, $\mathrm{PhD}^{6}$ Gerard J. Criner, $\mathrm{MD}^{7}$ Richard E. Kanner, $\mathrm{MD}^{8}$ Robert Paine III, MD ${ }^{8}$ Stephanie A. Christenson, MD $^{9}$ Christopher B. Cooper, MD $^{10}$ Igor Z. Barjaktarevic, MD $^{10}$ Jerry A. Krishnan, MD, PhD ${ }^{11}$ Wassim W. Labaki, MD ${ }^{12}$ MeiLan K. Han, MD ${ }^{12}$ Jeffrey L. Curtis, MD ${ }^{12,13}$ Nadia N. Hansel, $\mathrm{MD}^{14}$ Robert A. Wise, $\mathrm{MD}^{14}$ M. Bradley Drummond, MD, MHS ${ }^{1,2}$ for the SPIROMICS collaborators*

\begin{abstract}
Rationale: The antimicrobial peptide cathelicidin, also known in humans as LL-37, is a defensin secreted by immune and airway epithelial cells. Deficiencies in this peptide may contribute to adverse pulmonary outcomes in chronic obstructive pulmonary disease (COPD).

Objectives: Using clinical and biological samples from the SubPopulations and InteRmediate Outcome Measures In COPD Study (SPIROMICS), we assessed the associations of plasma cathelicidin levels with crosssectional and longitudinal COPD outcomes.

Methods: A total of 1609 SPIROMICS participants with COPD and available plasma samples were analyzed. Cathelicidin was modeled dichotomously (lowest quartile $[<50 \mathrm{ng} / \mathrm{ml}]$ versus highest $75 \%$ [ $\geq 50 \mathrm{ng} / \mathrm{ml}]$ ) and continuously per $10 \mathrm{ng} / \mathrm{ml}$. Fixed-effect multilevel regression analyses were used to assess associations between cathelicidin and cross-sectional as well as longitudinal lung function. The associations between cathelicidin and participant-reported retrospective and prospective COPD exacerbations were assessed via logistic regression. Measurements and Main Results: Cathelicidin $<50 \mathrm{ng} / \mathrm{ml}(\mathrm{N}=383)$ was associated with female sex, black race, and lower body mass index (BMI). At baseline, cathelicidin < $50 \mathrm{ng} / \mathrm{ml}$ was independently associated with $3.55 \%$ lower \% predicted forced expiratory volume in 1 second $\left(\mathrm{FEV}_{1}\right)(95 \%$ confidence interval [CI] $-6.22 \%$ to $-0.88 \%$ predicted; $p=0.01$ ), while every $10 \mathrm{ng} / \mathrm{ml}$ lower cathelicidin was independently associated with $0.65 \%$ lower \% predicted FEV 1 (95\% CI $-1.01 \%$ to $-0.28 \%$ predicted; $p<0.001$ ). No independent associations with longitudinal lung function decline or participant-reported COPD exacerbations were observed.

Conclusions: Reduced cathelicidin is associated with lower lung function at baseline. Plasma cathelicidin may potentially identify COPD patients at increased risk for more severe lung disease.
\end{abstract}

Abbreviations: chronic obstructive pulmonary disease, COPD; SubPopulations and InteRmediate Outcome Measures In COPD Study, SPIROMICS; body mass index, BMI; forced expiratory volume in 1 second, FEV $\mathbf{1}$; confidence interval, CI; airway surface liquid, ASL; acute exacerbations of COPD, AECOPD; C-reactive protein, CRP; white blood cell count, WBC; modified Medical Research Council dyspnea scale, mMRC; COPD Assessment Test, CAT; bronchodilator, BD; hydroxy, OH; standard deviation, SD 
Funding Support: SPIROMICS was supported by contracts from the National Institutes of Health and the National Heart, Lung and Blood Institute (HHSN268200900013C, HHSN268200900014C, HHSN268200900015C, HHSN268200900016C, HHSN268200900017C, HHSN268200900018C, HHSN268200900019C, HHSN268200900020C), which were supplemented by contributions made through the Foundation for the National Institutes of Health from AstraZeneca, Bellerophon Therapeutics, BoehringerIngelheim Pharmaceuticals, Inc., Chiesi Farmaceutici SpA, Forest Research Institute, Inc., GSK, Grifols Therapeutics, Inc., Ikaria, Inc., and Nycomed. RMB is supported by National Institutes of Health, National Heart, Lung and Blood Institute grant F32HL143867 MBD is supported by National Institutes of Health, National Heart, Lung and Blood Institute grant R01HL125432-06.

Date of Acceptance: May 27, 2020

Citation: Burkes RM, Ceppe AS, Couper DJ, et al. Plasma cathelicidin is independently associated with reduced lung function in COPD: analysis of the Subpopulations and Intermediate Outcome Measures In COPD Study Cohort. Chronic Obstr Pulm Dis. 2020;7(4):370-381. doi: https://doi.org/10.15326/jcopdf.7.4.2020.0142

1 Division of Pulmonary Diseases and Critical Care Medicine, University of North Carolina, Chapel Hill

2 Marsico Lung Institute, University of North Carolina, Chapel Hill

3 Gillings School of Global Public Health, University of North Carolina, Chapel Hill

4 Division of Pulmonary, Critical Care, and Occupational Medicine, Carver College of Medicine, University of Iowa, Iowa City

5 Division of Pulmonary, Allergy, and Critical Care Medicine, University of Alabama, Birmingham

6 Section of Pulmonary, Critical Care, Allergy, and Immunologic Disease, Wake Forest University, Winston-Salem, North Carolina

7 Division of Thoracic Medicine and Surgery, Temple University, Philadelphia, Pennsylvania

8 Division of Respiratory, Critical Care and Occupational Pulmonary Medicine, Department of Internal Medicine, School of Medicine, University of Utah, Salt Lake City

9 Division of Pulmonary Critical Care, Allergy, and Sleep Medicine, University of California, San Francisco

10 Division of Pulmonary and Critical Care Medicine, David Geffen School of Medicine, University of California, Los Angeles

11 Division of Pulmonary, Critical Care, Sleep, and Allergy Medicine, University of Illinois, Chicago

12 Division of Pulmonary and Critical Care Medicine, University of Michigan, Ann Arbor

13 Medicine Service, VA Ann Arbor Healthcare System, Ann Arbor, Michigan

14 Division of Pulmonary and Critical Care Medicine, Johns Hopkins University Baltimore, Maryland

* A complete list of SPIROMICS collaborators is provided in the Acknowledgements section.

\section{Address correspondence to:}

Robert M. Burkes, MD

130 Mason Farm Rd, CB\#7020

Chapel Hill, NC 27599

Phone: 919-966-2533

E-mail: burkesrt@ucmail.uc.edu

\section{Keywords:}

COPD; COPD outcomes; cathelicidin; immunology; innate immunity

\section{Introduction}

The innate immune system of the airways is the first line of defense from inhaled and aspirated pathogens and noxious agents. Alterations of innate immunity may play a role in the progression of chronic obstructive pulmonary disease (COPD). ${ }^{1-3}$ Cathelicidin (also known in humans as LL-37) is an antimicrobial peptide of the innate immune system present in the airway surface liquid (ASL), secreted by airway epithelial and immune cells. ${ }^{4-8}$ Cathelicidin gene transcription is regulated by 1,25 -hydroxyvitamin D. ${ }^{9}, 10$ Cathelicidin is expressed constitutively and induced in the presence of microbes, lipopolysaccharide, and inflammatory cytokines. ${ }^{11}$ Cathelicidin acts via direct microbial killing, immune cell signaling, increasing antigen-presenting cell activity, lipopolysaccharide neutralization, and signaling of epithelial cell apoptosis. ${ }^{8,12-15}$ Levels of both plasma and sputum cathelicidin have been shown to respond to the presence of pathogens or noxious stimuli. ${ }^{16-19}$

We have previously shown that reduced cathelicidin levels are associated with adverse pulmonary outcomes in non-COPD populations. In crosssectional analysis of a cohort of current and former injection drug users with prevalent smoking, lower plasma cathelicidin levels were associated with lower forced expiratory volume in 1 second $\left(F E V_{1}\right)$ and patient-reported pneumonia events. ${ }^{2}$ In longitudinal analyses of smokers without COPD, lower plasma cathelicidin has been associated with reduced $\mathrm{FEV}_{1}$ at 6 and 18 months. ${ }^{3}$ Studies have reported conflicting results regarding the association between cathelicidin level and COPD exacerbation (acute exacerbation of COPD [AECOPD]) risk. ${ }^{17,20}$ To our knowledge, there has been no investigation of the association between cathelicidin levels and longitudinal pulmonary outcomes in well-characterized COPD cohorts. 
The SubPopulations and InteRmediate Outcome Measures In COPD Study (SPIROMICS) is a prospective, multicenter cohort study with available baseline plasma and serum samples in addition to well-characterized demographic and clinical variables. ${ }^{21}$ SPIROMICS collects cross-sectional and longitudinal lung function measurements along with historical and prospective COPD exacerbations data. The SPIROMICS cohort allows for determination of relationships between cathelicidin levels and longitudinal lung function and exacerbation outcomes, as well as the association between cathelicidin and vitamin $\mathrm{D}$, a regulator of cathelicidin. We hypothesize that low plasma cathelicidin will be associated with reduced lung function and increased COPD exacerbations at enrollment and after one year of follow-up.

\section{Methods}

\section{Study Participants}

SPIROMICS (total cohort $\mathrm{n}=2974$ ) is a National Heart, Lung and Blood Institute-funded, multicenter, observational, prospective cohort developed to assess intermediate outcome measures and identify COPD subphenotypes. ${ }^{21}$ The cohort includes participants recruited from 12 clinical centers who are current or former smokers ( $\geq 20$ pack years) with or without chronic airflow obstruction and non-smoking controls between the ages of 40-80. The analytical cohort consists of 1609 participants with available plasma cathelicidin measurements and spirometry confirmed COPD (post-bronchodilator $\mathrm{FEV}_{1}$ to forced vital capacity $[F V C]$ ratio < 0.70) (Online Supplement Figure 1). Institutional review boards at each center approved SPIROMICS and participants provided informed, written consent.

\section{Data Collection}

Demographic data, medical history, self-reported smoking status (current versus former), smoking history (in pack years), and body mass index (BMI) were collected at enrollment. Post-bronchodilator spirometry values $\left(\mathrm{FEV}_{1}, \mathrm{FVC}, \mathrm{FEV}_{1} / \mathrm{FVC}\right.$ ) were collected and standardized according to published standards. $^{22}$ Historical AECOPD events were participant-reported at enrollment and involve any or severe AECOPD events in the 365 days prior to enrollment. Longitudinal AECOPD events were collected via participant self-report by quarterly phone calls and at a 1-year follow-up visit 365 days after study enrollment. An AECOPD event was defined as the need for any increased therapy due to COPD symptoms. Severe AECOPD was defined as an acute worsening of COPD symptoms leading to an emergency department visit or hospitalization. Stored baseline plasma samples were used to measure cathelicidin using ELISA (Hycult, Inc; limit of detection: $0.14 \mathrm{ng} / \mathrm{ml}$, standard range: $0.14 \mathrm{ng} /$ $\mathrm{ml}$ to $100 \mathrm{ng} / \mathrm{ml}$ ) and serum 25-hydroxy vitamin D via radioimmunoassay (iDS, Enzyme Immunoassay; Intra-assay coefficient of variance: $8.14 \%$, limit of blank: $1.8 \mathrm{ng} / \mathrm{ml}$ and limit of detection: $3.7 \mathrm{ng} / \mathrm{ml}$ ).

\section{Statistical Approach}

The cathelicidin distribution within the cohort was characterized using descriptive statistics. Cathelicidin levels were dichotomized using a cutpoint of the lowest quartile $(<50 \mathrm{ng} / \mathrm{ml})$ versus the highest 3 quartiles ( $\geq 50 \mathrm{ng} / \mathrm{ml}$ ) from SPIROMICS measurements conducted for this analysis, as well as continuously (per $10 \mathrm{ng} / \mathrm{ml}$ ). Two-sample t-test and Mann-Whitney $U$ testing for continuous variables (depending on skew of data) or chi-squared testing (for categorical variables) was performed to identify the differences in demographic and clinical factors between participants with cathelicidin < $50 \mathrm{ng} /$ $\mathrm{ml}$ versus $\geq 50 \mathrm{ng} / \mathrm{ml}$. Counts and percentages presented in Table 1 account for variable missingness, which is less than $10 \%$ for each variable and assumed to be random. For analyses, FEV 1 was modeled continuously as \% predicted FEV 1 . Linear regression modeling was used to determine bivariate relationships between cathelicidin and baseline \% predicted FEV . Fixed-effect multilevel modeling was used to determine multivariable relationships between continuous and categorical cathelicidin and $\%$ predicted $\mathrm{FEV}_{1}$ at baseline and rate of change over one year. Covariates in multivariable multilevel regression models were selected based on clinical relevance 23 and include pack years smoked and current smoking status (age, race, sex, and height are included in the calculation of $\mathrm{FEV}_{1} \%$ predicted). Any and severe AECOPD outcomes were modeled dichotomously ( 0 versus $\geq 1$ event) in logistic regression analysis. Multivariable models assessing the relationship between cathelicidin and AECOPD included age, race, sex, smoking status, pack years 


\section{Table 1. Cohort Characteristics}

\begin{tabular}{|c|c|c|c|c|}
\hline & Total & $\begin{array}{l}\text { Cathelicidin } \\
<50 \mathrm{ng} / \mathrm{ml}\end{array}$ & $\begin{array}{l}\text { Cathelicidin } \\
\geq 50 \mathrm{ng} / \mathrm{ml}\end{array}$ & $P$-value \\
\hline $\mathbf{N}$ & 1609 & 383 & 1226 & \\
\hline Age & $65.3(7.94)$ & $65.1(8.02)$ & $65.3(7.92)$ & 0.71 \\
\hline Female & $673(41.8)$ & $203(52.6)$ & $470(38.4)$ & $<0.001$ \\
\hline Black Race & $226(14.1)$ & $73(19.1)$ & $153(12.5)$ & 0.01 \\
\hline BMI, $\mathrm{kg} / \mathrm{m}^{2}$ & $27.3(5.25)$ & $25.7(5.12)$ & $27.9(5.19)$ & $<0.001$ \\
\hline Current Smoker & $529(33.5)$ & $136(36.4)$ & $393(32.6)$ & 0.17 \\
\hline Pack Years Smoking, median (Q1-Q3) & $46(30-57)$ & $46(33.75-66)$ & $46(36-61.5)$ & 0.84 \\
\hline \multicolumn{5}{|l|}{ mMRC Score } \\
\hline Median (Q1-Q3) & $1(1-2)$ & $1(1-2)$ & $1(1-2)$ & 0.13 \\
\hline $\mathrm{mMRC} \geq 2$ & $510(32.0)$ & $137(35.9)$ & $373(30.8)$ & 0.06 \\
\hline \multicolumn{5}{|l|}{ CAT score } \\
\hline Median (Q1-Q3) & $15(9-21)$ & $15(9-21)$ & $15(9-21)$ & 0.25 \\
\hline CAT $\geq 10$ & $1121(73.0)$ & 269 (73.9) & $852(72.7)$ & 0.51 \\
\hline FEV $_{1} /$ FVC ratio & $0.51(0.13)$ & $0.49(0.14)$ & $0.51(0.13)$ & 0.005 \\
\hline \multicolumn{5}{|l|}{ FEV $_{1}$} \\
\hline Total, post-BD, L & $1.75(0.79)$ & $1.58(0.75)$ & $1.81(0.79)$ & $<0.001$ \\
\hline$\%$ predicted, post-BD & $61.0(23.0)$ & $58.3(24.5)$ & $62.0(22.5)$ & 0.007 \\
\hline \multicolumn{5}{|l|}{ FVC } \\
\hline Total, post-BD, L & $3.37(1.06)$ & $3.13(1.01)$ & $3.44(1.06)$ & $<0.001$ \\
\hline$\%$ predicted, post-BD & $91.8(18.1)$ & $87.4(21.1)$ & 89.1 (19.6) & 0.13 \\
\hline History of Asthma & 447 (28.4) & $115(27.6)$ & $335(27.8)$ & 0.57 \\
\hline Chronic Bronchitis & $378(24.2)$ & $92(24.7)$ & $286(24.0)$ & 0.78 \\
\hline \multicolumn{5}{|l|}{ GOLD Severity } \\
\hline Stage 1 & $346(21.5)$ & $68(17.8)$ & $278(22.7)$ & \multirow[t]{4}{*}{0.01} \\
\hline Stage 2 & $712(44.3)$ & $157(41.0)$ & $555(45.3)$ & \\
\hline Stage 3 & $383(23.8)$ & $104(27.2)$ & $279(22.7)$ & \\
\hline Stage 4 & $159(9.90)$ & $50(13.1)$ & $109(8.90)$ & \\
\hline \multicolumn{5}{|l|}{ AECOPD in Previous Year, total } \\
\hline 0 & $1092(68.7)$ & $242(63.7)$ & $850(70.3)$ & \multirow[t]{3}{*}{0.01} \\
\hline 1 & $273(17.2)$ & 68 (17.9) & $205(17.0)$ & \\
\hline $2+$ & $224(14.0)$ & 70 (18.4) & 154 (12.6) & \\
\hline \multicolumn{5}{|l|}{ AECOPD in Previous Year, severe } \\
\hline 0 & $1336(84.3)$ & $310(81.6)$ & $1026(85.2)$ & \multirow[t]{3}{*}{0.13} \\
\hline 1 & $173(11.0)$ & $46(12.1)$ & $127(10.5)$ & \\
\hline $2+$ & $76(4.81)$ & $24(6.3)$ & $52(4.3)$ & \\
\hline
\end{tabular}

All values are $\mathrm{n}(\%)$ or mean $(\mathrm{SD})$ unless otherwise indicated

body mass index=BMI; mMRC=modified Medical Research Counsel score; $\mathrm{CAT}=\mathrm{COPD}$ Assessment Test; $\mathrm{FEV}_{1}=$ forced expiratory volume in 1 second; $\mathrm{FVC}=$ forced vital capacity; $\mathrm{BD}=$ bronchodilator; $\mathrm{GOLD}=\mathrm{Global}$ initiative for chronic Obstructive Lung Disease;

$\mathrm{AECOPD}=$ acute exacerbation of COPD

smoked, and BMI. Correlation between cathelicidin and vitamin $\mathrm{D}$ as well as other blood markers implicated in COPD progression and outcomes in prior publications ${ }^{24,25}$ were assessed by Pearson's correlation. These blood-based markers included
C-reactive protein (CRP), white blood cell (WBC) count, fibrinogen, interleukin-6, S100 calciumbinding protein, and club cell secretory protein-16.

Several sensitivity analyses were performed. Serum vitamin D levels were included in statistically 
significant models. Statistical moderation and stratified analysis incorporating vitamin $\mathrm{D}$ levels (categorical vitamin $\mathrm{D}$ deficiency $[<20 \mathrm{ng} / \mathrm{ml}$ 25-hydroxy (OH)-vitamin $\mathrm{D}]$ versus. sufficiency as well as continuous 25-OH-vitamin D) were conducted. For all comparisons $p<0.05$ was considered significant. Season of blood draw was added to statistically significant models. Statistical analysis was performed using SAS 9.4 (SAS, Cary, North Carolina).

\section{Results}

\section{Description of Cohort}

Demographic and clinical characteristics of the analytical cohort are summarized in Table 1 . The mean age was 65 years old, $42 \%$ were female, $14 \%$ reported Black race, and $34 \%$ were current smokers with a median smoking history of 46 pack years (Q1-Q3, 30-57). The total cohort baseline mean \% predicted $\mathrm{FEV}_{1}$ was $61.0 \%$ predicted (standard deviation [SD] $23 \%$ predicted) and \% predicted FVC was $91.8 \%$ predicted (SD $18.1 \%$ predicted). In the cohort, 34\% of participants were classified as Global initiative for chronic Obstructive Lung Disease (GOLD) ${ }^{26}$ stages 3 or 4 . Any COPD exacerbation in the year prior to enrollment was reported in $31 \%$ of participants and $16 \%$ reported a severe exacerbation in the year prior to study enrollment.

The median plasma cathelicidin level was $61.3 \mathrm{ng} / \mathrm{ml}$ (Q1-Q3, 50.6-74.4 ng/ml). There were 383 participants with cathelicidin $<50 \mathrm{ng} / \mathrm{ml}$ (lowest quartile) and 1226 with cathelicidin $\geq 50 \mathrm{ng} / \mathrm{ml}$. Participants with cathelicidin $<50 \mathrm{ng} / \mathrm{ml}$ were more likely to be female ( $53 \%$ versus $38 \% ; p<0.001$ ), Black (19\% versus $13 \% ; p<0.001$ ) and have a lower BMI (25.7 kg/m ${ }^{2}$ versus $27.9 \mathrm{~kg} / \mathrm{m}^{2}$; $p<0.001)$. Those with cathelicidin $<50 \mathrm{ng} / \mathrm{ml}$ had a lower baseline FEV 1 (1.58 L versus $1.81 \mathrm{~L}$; $p<0.001$ ), FVC (3.13 L versus $3.44 \mathrm{~L} ; p<0.001$ ), and $\mathrm{FEV}_{1} / \mathrm{FVC}(0.49$ versus $0.51 ; p=0.005)$. The $\%$ predicted post-bronchodilator baseline $\mathrm{FEV}_{1}$ was also lower among those with cathelicidin $<50 \mathrm{ng} / \mathrm{ml}$ (58\% predicted $F E V_{1}$ versus $62 \%$ predicted $F E V_{1}$, $p=0.007)$. Those with cathelicidin $<50 \mathrm{ng} / \mathrm{ml}$ were more likely to have GOLD stage 3 or 4 lung disease ( $40 \%$ versus $32 \%, p=0.01$ ), with lower median cathelicidin in more severe GOLD stages (Figure 1). Participants with cathelicidin $<50 \mathrm{ng} / \mathrm{ml}$

\section{Figure 1. Distribution of Plasma Cathelicidin Levels at Each Global Initiative for Chronic Obstructive Lung Disease Severity Stage}

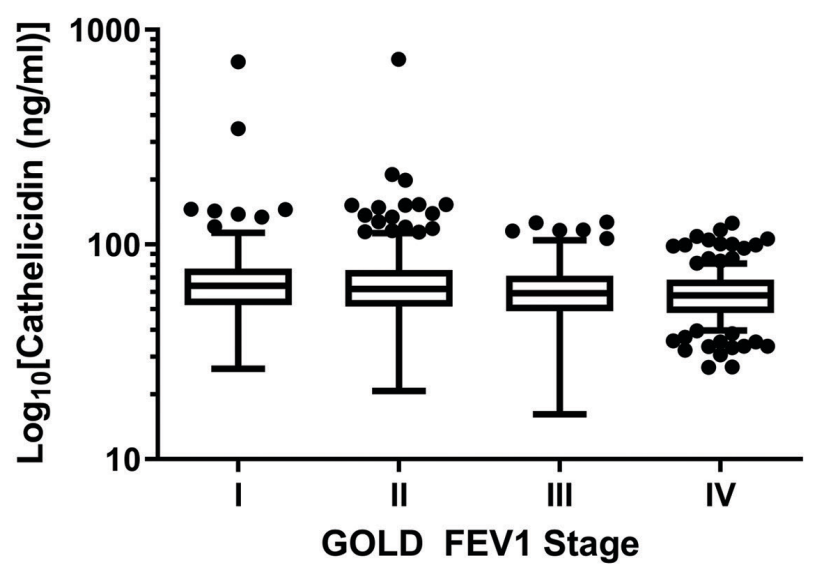

GOLD $=$ Global initiative for chronic Obstructive Lung Disease; $\mathrm{FEV}_{1}=$ forced expiratory volume in 1 second

were more likely to report at least 1 total COPD exacerbation in the year prior to admission (36\% versus $30 \%, p=0.01$ ). Serum vitamin $\mathrm{D}$ and plasma cathelicidin levels were not correlated $(r=0.03, p=$ 0.23). Of the blood markers previously associated with COPD progression and outcomes, only CRP $(\mathrm{r}=0.14, p<0.001)$ and total WBC count $(\mathrm{r}=0.16$, $p<0.001)$ were statistically correlated with cathelicidin levels, with low correlation coefficients (Online Supplement Table 1).

\section{Associations Between Cathelicidin Lung Function}

At baseline, in bivariate analysis cathelicidin $<50 \mathrm{ng} / \mathrm{ml}$ was associated with a $3.61 \%$ lower \% predicted $\mathrm{FEV}_{1}$ (95\% confidence interval [CI] $-6.26 \%$ to $-0.97 \%$ predicted $\left.\mathrm{FEV}_{1} ; p=0.007\right)$. When modeling cathelicidin continuously, in bivariable linear regression, every $10 \mathrm{ng} / \mathrm{ml}$ lower cathelicidin was associated with $0.53 \%$ lower \% predicted $\mathrm{FEV}_{1}$ (95\% CI $-0.91 \%$ to $-0.16 \%$ predicted $\mathrm{FEV}_{1}, p=0.006$ ) at baseline. At 1 year, in bivariate analysis, cathelicidin $<50 \mathrm{ng} / \mathrm{ml}$ was associated with a $4.00 \%$ lower \% predicted $\mathrm{FEV}_{1}$ (95\% CI $-7.03 \%$ to $-0.97 \%$ predicted $\left.\mathrm{FEV}_{1} ; p=0.01\right)$. Each $10 \mathrm{ng} / \mathrm{ml}$ lower cathelicidin was associated with a $0.53 \%$ lower $\%$ predicted $\mathrm{FEV}_{1}$ (95\% CI $-0.97 \%$ to $-0.16 \%$ predicted $\mathrm{FEV}_{1} ; p=0.005$ ) at 1 year.

In fixed-effect multivariable linear regression, 
controlling for current smoking and pack years smoked, cathelicidin $<50 \mathrm{ng} / \mathrm{ml}$ was associated with a $3.55 \%$ lower baseline \% predicted $\mathrm{FEV}_{1}$ (95\% CI $-6.22 \%$ to $-0.88 \%$ predicted $\mathrm{FEV}_{1} ; p=0.01$ ) (Table 2). Likewise, every $10 \mathrm{ng} / \mathrm{ml}$ lower cathelicidin was associated with a $0.65 \%$ lower baseline \% predicted $\mathrm{FEV}_{1}$ (95\% CI $-1.01 \%$ to $-0.28 \%$ predicted $\mathrm{FEV}_{1}$; $p<0.001$ ) (Table 3). Dichotomous and continuous cathelicidin were not associated with lower lung function at 1 year $\left(0.96 \%\right.$ lower $\%$ predicted $\mathrm{FEV}_{1}$ [95\% CI $-1.98 \%$ to $0.05 \%$ predicted $\mathrm{FEV}_{1} ; p=0.06$ ] and $0.04 \%$ lower \% predicted $\mathrm{FEV}_{1}$ [95\% CI $-0.17 \%$ to $0.08 \%$ predicted $\mathrm{FEV}_{1} ; p=0.49$ ], respectively).

\section{Associations Between Cathelicidin and Acute Exacerbation of COPD}

Logistic regression was used to determine the association between dichotomized and continuous cathelicidin levels with the odds of any AECOPD. In bivariate analysis, cathelicidin $<50 \mathrm{ng} / \mathrm{ml}$ was associated with a $35 \%$ increase in odds of total AECOPD in the past year (95\% CI 1.06-1.72; $p=0.02$ ). When controlled for age, race, sex, current smoking, pack years smoked, and BMI, the association was attenuated (odds ratio [OR] 1.29 [95\% CI 1.00-1.68]; $p=0.05$ ) (Table 4). Continuous cathelicidin was not associated with increased odds of exacerbation in bivariable logistic regression or when adjusted for the covariates above (OR 1.01 [95\% CI 0.97-1.05]; $p=0.76)$. When assessing associations between continuous or dichotomized cathelicidin levels and longitudinal total AECOPD events, there were no statistically significant bivariate or multivariable relationships observed (Table 5). There was no association between cathelicidin (dichotomized or continuous) and historical or longitudinal severe AECOPD (Online Supplement Tables 2 and 3, respectively).

\section{Sensitivity Analysis}

The addition of vitamin $D$ to the multilevel models did not attenuate the associations between continuous cathelicidin and $\%$ predicted $\mathrm{FEV}_{1}$ at baseline (0.62\% lower \% predicted $\mathrm{FEV}_{1}$ for every $10 \mathrm{ng} / \mathrm{ml}$ lower cathelicidin [95\% CI $-0.98 \%$ to $-0.26 \%$ predicted $\left.\left.\mathrm{FEV}_{1}\right] ; p=0.001\right)$. The relationship between cathelicidin $<50 \mathrm{ng} / \mathrm{ml}$ and baseline lung function was attenuated with the addition of vitamin $\mathrm{D}$ deficiency to the model $(0.96 \%$ lower \% predicted $\mathrm{FEV}_{1}$ [95\% CI $-1.96 \%$ to $0.05 \%$ predicted $\mathrm{FEV}_{1}$ ]; $p=0.06)$. The addition of season did not attenuate the association of either categorical or continuous cathelicidin with baseline \% predicted FEV 1 . There was no statistically significant interaction between cathelicidin and vitamin $\mathrm{D}$ levels with baseline or longitudinal lung function.

\section{Discussion}

In this analysis of 1609 COPD participants from the SPIROMICS cohort, we demonstrate that reduced plasma cathelicidin is independently associated with lower \% predicted FEV 1 at baseline. There was a nonstatistical trend toward lower $\%$ predicted $\mathrm{FEV}_{1}$ at

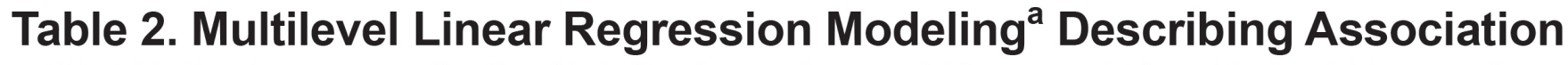 with Dichotomous Cathelicidin Levels and Percent Predicted Forced Expiratory Volume in 1 Second}

\begin{tabular}{|c|c|c|c|}
\hline & $\begin{array}{c}\text { Baseline } \\
\% \text { Predicted FEV } 1\end{array}$ & $\begin{array}{l}\% \text { Predicted FEV } 1 \text { Difference } \\
\text { from Baseline to Year } 1\end{array}$ & $P$ \\
\hline \multicolumn{4}{|l|}{ Baseline } \\
\hline Cathelicidin $(<50 \mathrm{vs} . \geq 50 \mathrm{ng} / \mathrm{ml})$ & $-3.55(-6.22$ to -0.88$)$ & --- & 0.01 \\
\hline Current Smoking & $-0.40(-1.72$ to 0.92$)$ & --- & 0.54 \\
\hline Pack Years Smoked, per 10 & $-0.14(-0.55$ to 0.26$)$ & --- & 0.49 \\
\hline \multicolumn{4}{|l|}{ Year 1} \\
\hline Cathelicidin $(<50$ vs. $\geq 50 \mathrm{ng} / \mathrm{ml})$ & --- & $-0.96(-1.98$ to 0.05$)$ & 0.06 \\
\hline Visit 1 vs. Baseline & --- & $-1.36(-2.26$ to -0.47$)$ & 0.003 \\
\hline
\end{tabular}

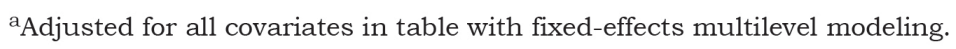

$\mathrm{FEV}_{1}=$ forced expiratory volume in 1 second 


\section{Table 3. Multilevel Linear Regression Modeling ${ }^{a}$ Describing Associations Between Continuous Cathelicidin Levels and Percent Predicted Forced Expiratory Volume in 1 Second}

\author{
Baseline \\ $\%$ Predicted FEV 1
}

$\%$ Predicted FEV 1 Difference

from Baseline to Year 1

\section{Baseline}

Cathelicidin (per $10 \mathrm{ng} / \mathrm{ml}$ decrease) $-0.65(-1.01$ to -0.28$)$

Current Smoking $-0.40(-1.72$ to 0.92$)$

Pack Years Smoked, per 10

$-0.15(-0.55$ to 0.26$)$

$--$ $<0.001$

$--$

Year 1

Cathelicidin (per $10 \mathrm{ng} / \mathrm{ml}$ decrease)

$--$

$-0.04(-0.17$ to 0.08$)$

0.49

Visit 1 vs. Baseline

$-0.90(-1.83$ to 0.02$)$

0.06



$\mathrm{FEV}_{1}=$ forced expiratory volume in 1 second

Table 4. Multivariable Logistic Regression Analysis ${ }^{\mathrm{a}}$ Describing the Associations Between Dichotomous Cathelicidin and Odds of Total COPD Exacerbations in the Year Prior to Enrollment

\begin{tabular}{l|c|c}
\hline $\begin{array}{l}\text { Cathelicidin } \\
\text { (<50 vs. } \geq 50 \mathrm{ng} / \mathrm{ml})\end{array}$ & $1.29(1.00-1.68)$ & 0.05 \\
\hline Age, per 10 years & $0.59(0.50-0.69)$ & $<0.001$ \\
\hline Black Race & $1.33(0.97-1.82)$ & 0.08 \\
\hline Female & $1.66(1.32-2.07)$ & $<0.001$ \\
\hline Current Smoking & $0.50(0.38-0.65)$ & $<0.001$ \\
\hline Pack Years Smoked, & $0.94(0.86-1.06)$ & 0.18 \\
per 10 pack years & & \\
\hline BMI, $\mathrm{kg} / \mathrm{m}^{2}$ & $1.00(0.98-1.03)$ & 0.78 \\
\hline
\end{tabular}

${ }^{\mathrm{a}}$ Multivariable logistic regression controlled for all covariates in table.

$\mathrm{OR}=$ odds ratio; $\mathrm{BMI}=$ body mass index

1 year in individuals with cathelicidin $<50 \mathrm{ng} / \mathrm{ml}$. Similarly, low cathelicidin was associated with a trend in increased reported AECOPD events in the year prior to study enrollment. To our knowledge, this is the first description of associations between reduced plasma cathelicidin and lung function decrements in a COPD cohort. These results are strengthened by analyzing data from one of the largest, most comprehensively-phenotyped U.S. COPD cohorts using mixed-model analyses. These findings demonstrate that low cathelicidin identifies those COPD patients with lower lung function and may inform adverse longitudinal lung outcomes.

\section{Table 5. Multivariable Logistic Regression Analysis ${ }^{\mathrm{a}}$ Describing the Associations Between Continuous Cathelicidin and Odds of Total COPD Exacerbations in the Year Prior to Enrollment}

\begin{tabular}{|c|c|c|}
\hline & OR $(95 \% \mathrm{Cl})$ & P-value \\
\hline $\begin{array}{l}\text { Cathelicidin } \\
\text { (per } 10 \mathrm{ng} / \mathrm{ml} \text { lower) }\end{array}$ & $1.01(0.97-1.05)$ & 0.76 \\
\hline Age, per 10 years & $0.59(0.50-0.69)$ & $<0.001$ \\
\hline Black Race & $1.36(0.99-1.86)$ & 0.06 \\
\hline Female & $1.67(1.33-2.09)$ & $<0.001$ \\
\hline Current Smoking & $0.50(0.38-0.65)$ & $<0.001$ \\
\hline $\begin{array}{l}\text { Pack Years Smoked, } \\
\text { per } 10 \text { pack years }\end{array}$ & $1.00(0.98-1.02)$ & 0.21 \\
\hline BMI, $\mathrm{kg} / \mathrm{m}^{2}$ & $1.00(0.98-1.02)$ & 0.94 \\
\hline \multicolumn{3}{|c|}{$\begin{array}{l}{ }^{a} \text { Multivariable logistic regression controlled for all covariates } \\
\text { in table. }\end{array}$} \\
\hline
\end{tabular}

We have previously shown a relationship between low cathelicidin and decreased longitudinal lung function in smokers without COPD. ${ }^{3}$ In that study, plasma cathelicidin $<35 \mathrm{ng} / \mathrm{ml}$ (representing the lowest quartile in the study cohort) was associated with a $72 \mathrm{ml}$ lower $\mathrm{FEV}_{1}$ at 6 months and a $103 \mathrm{ml}$ lower FEV 1 at 18 months from baseline. The findings of this analysis extend the previously described associations between lower plasma cathelicidin and lung function impairments to a population with established COPD. Opposite from the associations in smokers without COPD, we observed an association between baseline $\mathrm{FEV}_{1}$ and low cathelicidin, with a 
non-statistically significant trend in longitudinal $\mathrm{FEV}_{1}$ decline. These findings may reflect that reduced cathelicidin is a stronger marker in smokers with preserved lung function due to the propensity for those with greater lung function to be more susceptible to lung function declines than those with established, more severe COPD. ${ }^{27}$ In established COPD, the association between low cathelicidin and reduced baseline lung function could reflect the longitudinal losses that occurred earlier in life. While our findings expand on the potential role of using cathelicidin as a marker of COPD patients at a high risk for lung function impairments, they also suggest that these measurements may be more valuable in at-risk smokers and those with relatively mild obstruction.

Identifying blood-based markers contributing to the development and progression of COPD is a key research goal. Some blood-based markers have been associated with disease progression in various combinations, ${ }^{28}$ while others have shown variable consistency in associations across large COPD cohorts. ${ }^{21,29-32}$ In this analysis, plasma cathelicidin levels were weakly correlated with CRP and WBC count. If externally validated in other COPD cohorts, the association between reduced cathelicidin and adverse pulmonary outcomes raises the possibility that this peptide could serve as a potential biomarker to inform risk stratification in COPD.

Low plasma cathelicidin levels may reflect a deficiency in the innate immune system. Studies in cathelicidin gene knock-out mice and cultured epithelium have described decreased viral ${ }^{14}$ and bacterial clearance, ${ }^{33-35}$ increased bacterial biofilm formation, ${ }^{36,37}$ differential mucociliary cell activity, ${ }^{38}$ and decreased epithelial integrity ${ }^{39}$ in cathelicidindeficient states. Host-microbiome interactions and the response to environmental irritants may be altered by less robust innate immunity ${ }^{40}$ leading to colonization of more pathologic bacteria in the airways, further propagating the dysbiosis and inflammatory cycle characteristic of COPD. ${ }^{41}$ This potential mechanism is supported by previous observations of increased incident pneumonia in cathelicidin-deficient states. ${ }^{2}$ In COPD, infection risk can manifest through COPD exacerbations. We did not observe an independent association between reduced cathelicidin level and increased COPD exacerbation risk. This lack of an association may be due to underpowering given the few COPD exacerbation events in SPIROMICS. ${ }^{42}$ Alternatively, cathelicidin may not be implicated in the causal pathway for exacerbations.

Cathelicidin is regulated by vitamin D. ${ }^{9}$ In our analysis, plasma cathelicidin was not correlated with serum vitamin $D$. The addition of vitamin $D$ attenuated the relationship between baseline lung function and categorical cathelicidin. Associations between blood vitamin D and cathelicidin levels have been inconsistent. ${ }^{2,3,17}$ Mechanistically, vitamin D interacts with the immune system through multiple pathways. ${ }^{43-46}$ Investigations have shown increased ASL cathelicidin levels and antimicrobial activity after supplementation with vitamin D, suggesting biological plausibility of an in vivo vitamin D-cathelicidin relationship. ${ }^{47}$ Randomized controlled trials assessing vitamin $D$ supplementation to prevent infectious episodes have enrolled patients who were at or near vitamin $D$ sufficiency, ${ }^{48,49}$ potentially selecting for cohorts less likely to see beneficial response from supplementation. Cathelicidin levels were not measured in these trials. Our study suggests that a relationship between cathelicidin and lung function may not be independent of vitamin $D$ and may inform future studies using plasma cathelicidin levels or antimicrobial activity as a marker for response to vitamin $\mathrm{D}$ supplementation in trials including participants with COPD.

This study has limitations. As an observational study, our results are insufficient to establish a causal relationship between low cathelicidin and lung function decline. This study would benefit from external validation in additional COPD cohorts. Given the relatively low frequency of AECOPD events in the SPIROMICS cohort, ${ }^{42}$ we may be underpowered to detect a true association between AECOPD and cathelicidin. Similarly, 1 year is a short period to determine longitudinal changes in FEV 1 . However, this limitation illustrates the need for determining the stability and meaningfulness of cathelicidin levels and relationships with lung function decline over time. Studies have reported serum ${ }^{16}$ and sputum $^{16-19}$ cathelicidin measurements in COPD. Whether cathelicidin concentration in the blood is reflective of the levels and activity in the airways is not fully determined, ${ }^{10}$ but blood levels have been associated with meaningful COPD outcome ${ }^{2,3}$ and increase under the stress of microbial infections or noxious stimuli similar to sputum levels. ${ }^{16}$ Similarly, 
we do not have microbiome data as part of this analysis. Medication usage (e.g., azithromycin or inhaled corticosteroids) was not included in our models and could potentially introduce residual confounding, although literature on these agents and plasma cathelicidin is not available.

In conclusion, we report an independent association between lower plasma cathelicidin and reduced lung function at baseline. Low cathelicidin was associated with trends toward lower lung function at 1 year that did not reach statistical significance. There was no robust association between cathelicidin and COPD exacerbations. Our findings extend the observations of reduced cathelicidin and impaired lung function from at-risk individuals to those with established COPD. This study implicates cathelicidin as a measurable component of the innate immune system potentially informative of the risk of lung function impairments in COPD. If validated in other COPD cohorts, plasma cathelicidin may serve as a potential marker to identify COPD patients at increased risk for adverse lung outcomes. Ultimately, mechanisms to augment cathelicidin may serve as a pharmacological target to improve the health of individuals at risk or with COPD.

\section{Acknowledgements}

The authors thank the SPIROMICS participants and participating physicians, investigators and staff for making this research possible. More information about the study and how to access SPIROMICS data is at www.spiromics.org. We would like to acknowledge the following current and former investigators of the SPIROMICS sites and reading centers: Neil E. Alexis, PhD; Wayne H. Anderson, PhD; R. Graham Barr, MD, DrPH; Eugene R. Bleecker, MD; Richard C. Boucher, MD; Russell P. Bowler, MD, PhD; Elizabeth E. Carretta, MPH; Stephanie A. Christenson, MD; Alejandro P. Comellas, MD; Christopher B. Cooper, MD, PhD; David J. Couper, PhD; Gerard J. Criner, MD; Ronald G. Crystal, MD; Jeffrey L. Curtis, MD; Claire M. Doerschuk, MD; Mark T. Dransfield, MD; Christine M. Freeman, PhD; MeiLan K. Han, MD, MS; Nadia N. Hansel, MD, MPH; Annette T. Hastie, PhD; Eric A. Hoffman, PhD; Robert J. Kaner, MD; Richard E. Kanner, MD; Eric C. Kleerup, MD; Jerry A. Krishnan, $\mathrm{MD}, \mathrm{PhD}$; Lisa M. LaVange, PhD; Stephen C. Lazarus, MD; Fernando J. Martinez, MD, MS; Deborah A. Meyers, PhD; John D. Newell, Jr., MD; Elizabeth C.
Oelsner, MD, MPH; Wanda K. O’Neal, PhD; Robert Paine, III, MD; Nirupama Putcha, MD, MHS; Stephen I. Rennard, MD; Donald P. Tashkin, MD; Mary Beth Scholand, MD; J. Michael Wells, MD; Robert A. Wise, MD; and Prescott G. Woodruff, MD, MPH. The project officers from the Lung Division of the National Heart, Lung, and Blood Institute were Lisa Postow, PhD, and Thomas Croxton, PhD, MD.

Author contributions: RMB, ASC, MBD conceptualized the study. ASC and RMB performed data analysis. RMB and MBD drafted the original manuscript. All coauthors were involved in collection of data, interpretation of of data, and critical review and revision of this manuscript.

\section{Declaration of Interest}

RMB is supported through grants from the National Institutes of Health. APC receives grants from the National Institutes of Health and receives consulting fees from VIDA. JMW receives grants from the National Institutes of Health. GJC receives grants from the National Institutes of Health and receives consulting fees from Novartis, AstraZeneca, Respironics, MedImmune, Actelion, Forest, and Pearl. REK receives contracts and grants from the National Institutes of Health. RP receives grants from the National Institutes of Health and research monies from the COPD Foundation. SAC receives grants from the National Institutes of Health and consulting fees from GlaxoSmithKline, Amgen, Glenmark, Sunovion, Genetech and MedImmune. CBC receives grants from the National Institutes of Health and contracts from the National Institutes of Health Foundation. IZB has consulting fees from Amgen, Theravance, GE Healthcare, AstraZeneca, GlaxoSmithKline, Boehringer Ingelheim and Verona Pharma. JAK receives grants from the National Institutes of Health and the Patient-Centered Outcomes Research Institute and consulting fees from Inogen. $\mathrm{MKH}$ receives grants from the National Institutes of Health. JLC receives grants from the National Institutes of Health. $\mathrm{NNH}$ receives grants from the National Institutes of Health and the COPD Foundation and has contracts from AstraZeneca, Boehringer Ingelheim and Mylan. RAW receives consulting fees from AstraZeneca, Boehringer Ingelheim, Contrafect, Pulmonx, Roche, Spiration and Sunovion. MBD receives grants from the National Institutes of Health. ASC, DJC, SPP, and WWL have nothing to declare. 


\section{References}

1. 1. Caramori G, Casolari P, Barczyk A, Durham AL, Di Stefano A, Adcock I. COPD immunopathology. Semin Immunopathol. 2016;38(4):497-515.

doi: https://doi.org/10.1007/s00281-016-0561-5

2. Lambert AA, Kirk GD, Astemborski J, et al. A cross sectional analysis of the role of the antimicrobial peptide cathelicidin in lung function impairment within the ALIVE cohort. PloS One. 2014;9(4):e95099.

doi: https://doi.org/10.1371/journal.pone.0095099

3. Burkes RM, Astemborski J, Lambert AA, et al. Plasma cathelicidin and longitudinal lung function in current and former smokers. PloS One. 2019;14(2):e0212628.

doi: https://doi.org/10.1371/journal.pone.0212628

4. Jiang YY, Xiao W, Zhu MX, et al. The effect of human antibacterial peptide LL-37 in the pathogenesis of chronic obstructive pulmonary disease. Respir Med. 2012;106(12):16801689. doi: https://doi.org/10.1016/j.rmed.2012.08.018

5. Davidson DJ, Currie AJ, Reid GS, et al. The cationic antimicrobial peptide LL-37 modulates dendritic cell differentiation and dendritic cell-induced $\mathrm{T}$ cell polarization. $J$ Immunol. 2004; 172(2): 1146-1156.

doi: https://doi.org/10.4049/jimmunol.172.2.1146

6. Nagaoka I, Tamura H, Hirata M. An antimicrobial cathelicidin peptide, human CAP18/LL-37, suppresses neutrophil apoptosis via the activation of formyl-peptide receptor-like 1 and P2X7. J Immunol. 2006;176(5):3044-3052.

doi: https://doi.org/10.4049/jimmunol.176.5.3044

7. De Y, Chen Q, Schmidt AP, Anderson GM, et al. LL-37, the neutrophil granule- and epithelial cell-derived cathelicidin, utilizes formyl peptide receptor-like 1 (FPRL1) as a receptor to chemoattract human peripheral blood neutrophils, monocytes, and T cells. J Exp Med. 2000;192(7):1069-1074.

doi: https://doi.org/10.1084/jem.192.7.1069

8. Zanetti M. Cathelicidins, multifunctional peptides of the innate immunity. J Leukoc Biol. 2004;75(1):39-48.

doi: https://doi.org/10.1189/jlb.0403147

9. White JH. Vitamin D as an inducer of cathelicidin antimicrobial peptide expression: past, present and future. J Steroid Biochem Mol Biol. 2010;121(1-2):234-238.

doi: https://doi.org/10.1016/j.jsbmb.2010.03.034

10. Yim S, Dhawan P, Ragunath C, Christakos S, Diamond G. Induction of cathelicidin in normal and CF bronchial epithelial cells by 1,25-dihydroxyvitamin D(3). J Cyst Fibros. 2007;6(6):403410. doi: https://doi.org/10.1016/j.jcf.2007.03.003

11. Gombart AF, Borregaard N, Koeffler HP. Human cathelicidin antimicrobial peptide (CAMP) gene is a direct target of the vitamin D receptor and is strongly up-regulated in myeloid cells by 1,25-dihydroxyvitamin D3. FASEB J. 2005;19(9):1067-1077. doi: https://doi.org/10.1096/f.04-3284com
12. Amatngalim GD, Schrumpf JA, Henic A, et al. Antibacterial defense of human airway epithelial cells from chronic obstructive pulmonary disease patients induced by acute exposure to nontypeable haemophilus influenzae: modulation by cigarette smoke. J Innate Immun. 2017;9(4). doi: https://doi.org/10.1159/000455193

13. Heulens N, Korf H, Mathyssen C, et al. 1,25-Dihydroxyvitamin $\mathrm{D}$ modulates antibacterial and inflammatory response in human cigarette smoke-exposed macrophages. PloS One. 2016;11(8):e0160482.

doi: https://doi.org/10.1371/journal.pone.0160482

14. Currie SM, Gwyer Findlay E, McFarlane AJ, et al. Cathelicidins have direct antiviral activity against respiratory syncytial virus in vitro and protective function in vivo in mice and humans. $J$ Immunol. 2016;196(6):2699-2710. doi: https://doi.org/10.4049/jimmunol.1502478

15. Sousa FH, Casanova V, Findlay F, et al. Cathelicidins display conserved direct antiviral activity towards rhinovirus. Peptides. 2017;95:76-83.

doi: https://doi.org/10.1016/j.peptides.2017.07.013

16. Pouwels SD, Nawijn MC, Bathoorn E, et al. Increased serum levels of LL37, HMGB1 and S100A9 during exacerbation in COPD patients. Eur Respir J. 2015;45(5):1482-1485. doi: https://doi.org/10.1183/09031936.00158414

17. Persson LJ, Aanerud M, Hardie JA, et al. Antimicrobial peptide levels are linked to airway inflammation, bacterial colonisation and exacerbations in chronic obstructive pulmonary disease. Eur Respir J. 2017;49(3):1601328.

doi: https://doi.org/10.1183/13993003.01328-2016

18. Parameswaran GI, Sethi S, Murphy TF. Effects of bacterial infection on airway antimicrobial peptides and proteins in COPD. Chest. 2011;140(3):611-617.

doi: https://doi.org/10.1378/chest.10-2760

19. Mallia P, Footitt J, Sotero R, et al. Rhinovirus infection induces degradation of antimicrobial peptides and secondary bacterial infection in chronic obstructive pulmonary disease. Am J Respir Crit Care Med. 2012;186(11):1117-1124.

doi: https://doi.org/10.1164/rccm.201205-0806OC

20. Yang YM, Guo YF, Zhang HS, Sun TY. Antimicrobial peptide LL37 circulating levels in chronic obstructive pulmonary disease patients with high risk of frequent exacerbations. J Thorac Dis. 2015;7(4):740-745.

doi: https://doi.org/10.3978/j.issn.2072-1439.2015.04.33 .

21. Couper D, LaVange LM, Han M, et al. Design of the Subpopulations and Intermediate Outcomes in COPD Study (SPIROMICS). Thorax. 2014;69(5):491-494. doi: https://doi.org/10.1136/thoraxjnl-2013-203897 .

22. Miller MR, Hankinson J, Brusasco V, et al. Standardisation of spirometry. Eur Respir J. 2005;26(2):319-338. doi: https://doi.org/10.1183/09031936.05.00034805 
23. Lederer DJ, Bell SC, Branson RD, et al. Control of confounding and reporting of results in causal inference studies. Guidance for authors from editors of respiratory, sleep, and critical care journals. Ann Am Thorac Soc. 2019;16(1):22-28. doi: https://doi.org/10.1513/AnnalsATS.201808-564PS

24. Fermont JM, Masconi KL, Jensen MT, et al. Biomarkers and clinical outcomes in COPD: a systematic review and metaanalysis. Thorax. 2019;74(5):439-446.

doi: https://doi.org/10.1136/thoraxjnl-2018-211855

25. Mannino DM. Biomarkers for chronic obstructive pulmonary disease diagnosis and progression: insights, disappointments and promise. Curr Opin Pulm Med. 2018;25(2):144-149. doi: https://doi.org/10.1097/MCP.0000000000000549

26. Global Initiative for Chronic Obstructive Lung Disease (GOLD). Global strategy for the diagnosis, management and prevention of COPD. GOLD website. Published 2020. Accessed May 2020. https://goldcopd.org/wp-content/uploads/2019/12/GOLD2020-FINAL-ver1.2-03Dec19_WMV.pdf

27. Berry CE, Drummond MB. The horse-racing effect and lung function: can we slow the fastest horse? Am J Respir Critical Care Med, 2017;195(9):1134-1135.

doi: https://doi.org/10.1164/rccm.201703-0540ED

28. Zemans RL, Jacobson S, Keene J, et al. Multiple biomarkers predict disease severity, progression and mortality in COPD. Respir Res. 2017;18(1):117.

doi:.https://doi.org/10.1186/s12931-017-0597-7

29. Regan EA, Hokanson JE, Murphy JR, et al. Genetic epidemiology of COPD (COPDGene) study design. COPD. 2010;7(1):32-43. doi: https://doi.org/10.3109/15412550903499522

30. Wells JM, Parker MM, Oster RA, et al. Elevated circulating MMP9 is linked to increased COPD exacerbation risk in SPIROMICS and COPDGene. JCI Insight. 2018;3(22).

doi: https://doi.org/10.1172/jci.insight.123614

31. Fawzy A, Putcha N, Aaron CP, et al. Aspirin use and respiratory morbidity in COPD: a propensity score-matched analysis in Subpopulations and Intermediate Outcome Measures in COPD Study. Chest. 2019;155(3):519-527.

doi: https://doi.org/10.1016/j.chest.2018.11.028

32. Keene JD, Jacobson S, Kechris K, et al. Biomarkers predictive of exacerbations in the SPIROMICS and COPDGene cohorts. Am $J$ Respir Crit Care Med. 2017;195(4):473-481. doi: https://doi.org/10.1164/rccm.201607-13300C

33. Gupta S, Winglee K, Gallo R, Bishai WR. Bacterial subversion of cAMP signalling inhibits cathelicidin expression, which is required for innate resistance to Mycobacterium tuberculosis. $J$ Pathol. 2017;242(1):52-61. doi: https://doi.org/10.1002/path.4878
34. Kovach MA, Ballinger MN, Newstead MW, et al. Cathelicidinrelated antimicrobial peptide is required for effective lung mucosal immunity in Gram-negative bacterial pneumonia. $J$ Immunol. 2012;189(1):304-311.

doi: https://doi.org/10.4049/jimmunol.1103196

35. Beaumont PE, McHugh B, Gwyer Findlay E, et al. Cathelicidin host defence peptide augments clearance of pulmonary Pseudomonas aeruginosa infection by its influence on neutrophil function in vivo. PloS One. 2014;9(6):e99029. doi: https://doi.org/10.1371/journal.pone.0099029

36. Amer LS, Bishop BM, van Hoek ML. Antimicrobial and antibiofilm activity of cathelicidins and short, synthetic peptides against Francisella. Biochem Biophys Res Commun. 2010;396(2):246-251.

doi: https://doi.org/10.1016/j.bbrc.2010.04.073

37. Overhage J, Campisano A, Bains M, Torfs ECW, Rehm BHA, Hancock REW. Human host defense peptide LL-37 prevents bacterial biofilm formation. Infect Immun. 2008;76(9):4176-4182. doi: https://doi.org/10.1128/IAI.00318-08

38. Zuyderduyn S, Ninaber DK, Schrumpf JA, et al. IL-4 and IL13 exposure during mucociliary differentiation of bronchial epithelial cells increases antimicrobial activity and expression of antimicrobial peptides. Respir Res. 2011;12:59. doi: https://doi.org/10.1186/1465-9921-12-59

39. Shaykhiev R, Sierigk J, Herr C, Krasteva G, Kummer W, Bals R. The antimicrobial peptide cathelicidin enhances activation of lung epithelial cells by LPS. FASEB J. 2010;24(12):4756-4766. doi: https://doi.org/10.1096/f.09-151332

40. Hiemstra PS, Amatngalim GD, van der Does AM, Taube C. Antimicrobial peptides and innate lung defenses: role in infectious and noninfectious lung diseases and therapeutic applications. Chest. 2016;149(2):545-551.

doi: https://doi.org/10.1378/chest.15-1353

41. Marsland BJ, Gollwitzer ES. Host-microorganism interactions in lung diseases. Nat Rev Immunol. 2014;14(12):827-835. doi: https://doi.org/10.1038/nri3769

42. Han MK, Quibrera PM, Carretta EE, et al. Frequency of exacerbations in patients with chronic obstructive pulmonary disease: an analysis of the SPIROMICS cohort. Lancet Respir Med. 2017;5(8):619-626.

doi: https://doi.org/10.1016/S2213-2600(17)30207-2

43. Samuel S, Sitrin MD. Vitamin D's role in cell proliferation and differentiation. Nutr Rev. 2008;66(10 Suppl 2):S116-24. doi: https://doi.org/10.1111/j.1753-4887.2008.00094.x

44. Zhang Y, Leung DY, Richers BN, et al. Vitamin D inhibits monocyte/macrophage proinflammatory cytokine production by targeting MAPK phosphatase-1. J Immunol. 2012;188(5):21272135. doi: https://doi.org/10.4049/jimmunol.1102412 
45. Cantorna MT, Yu S, Bruce D. The paradoxical effects of vitamin D on type 1 mediated immunity. Mol Aspects Med. 2008;29(6):369375. doi: https://doi.org/10.1016/j.mam.2008.04.004

46. Gombart AF. The vitamin D-antimicrobial peptide pathway and its role in protection against infection. Future Microbiol. 2009;4(9):1151-1165. doi: https://doi.org/10.2217/fmb.09.87

47. Vargas Buonfiglio LG, Cano M, Pezzulo AA, et al. Effect of vitamin $D$ on the antimicrobial activity of human airway surface liquid: preliminary results of a randomised placebo-controlled double-blind trial. BMJ Open Respir Res. 2017;4(1):e000211. doi: https://doi.org/10.1136/bmjresp-2017-000211

48. Lehouck A, Mathieu C, Carremans C, et al. High doses of vitamin $\mathrm{D}$ to reduce exacerbations in chronic obstructive pulmonary disease: a randomized trial. Ann Int Med. 2012;156(2):105-114. doi: https://doi.org/10.7326/0003-4819-156-2-201201170-00004

49. Murdoch DR, Slow S, Chambers ST, et al. Effect of vitamin D3 supplementation on upper respiratory tract infections in healthy adults: the VIDARIS randomized controlled trial. JAMA. 2012;308(13):1333-1339.

doi: https://doi.org/10.1001/jama.2012.12505 